\title{
On the Three Themes of Heart of Darkness
}

\author{
ZHANG Song-cun \\ Sichuan University of Arts and Science, Dazhou, China
}

\begin{abstract}
Heart of Darkness is one of the masterpieces of Joseph Conrad (1857-1924), which shows the author's great humanity and his unreserved horror at the crimes committed by the colonists and imperialists all over the world. This thesis tries to analyze its three themes: the Colonists' material essence, the dark side of human nature, and the disillusionment of civilization. Kurtz, the main character in the novel, is characterized by his greed for material gain and power. The dark side of human nature is reflected in Kurtz's cruel behavior towards the natives, his sense of superiority to the marginalized, and his dominance in discourse over the colonial people. Along with the colonists' crazy behaviors, there is disillusion with the modern civilization.
\end{abstract}

Keywords: Heart of Darkness, colonists, human nature, disillusionment of civilization

\section{Introduction}

Heart of Darkness (1902) has been viewed as one of the greatest of Joseph Conrad's stories (CHEN, 1990, p. 167). As soon as it was published, it drew many critics' attention. They analyze this story from many perspectives, such as the writing skills of the novel, morality, psychology, reader's reflection and its influence, racial prejudice, sexual prejudice, etc. So the theme of this novel is very controversial. In order to give a most justifiable analysis of the theme of this novel, it is better to know the author's tenet in literary creation first. In 1897, Conrad declared publicly in his famous "Preface" to The Nigger of the Narcissus that he believed that an artist's major concern should be revealing the truth (Conrad, 1999, p. iii). Therefore the theme of Heart of Darkness should be studied with the light of this declaration.

The truth embedded in Heart of Darkness lies in three aspects. Firstly, this novel exposes the true nature of colonialism, which is colonists' material essence. It discloses the cruelty and fraudulence in colonial activities, and questions the justifiability of commercialism. Secondly, it probes into the dark side of human being, the most primitive form of human existence, and the hidden meaning in the frenzy lives of trees, grass, black natives, and white colonists that struggle against each other in the terrible tropical climate. In Heart of Darkness, Conrad reveals the enslavement of human beings by their own desire and external forces, and shows some solutions to free oneself from this enslavement, such as detachment from desire and external forces and compassion for others' suffering. Thirdly, there is disillusionment with the civilization. The colonists claimed to bring civilization to Africa. On the contrary, they made the local environment worse. After experiencing hope, regret, and fear, seeing Kurtz died in fear, Marlow found the truth, and suddenly felt life is nothing, without purpose and meaning.

ZHANG Song-cun, lecturer, M.A., School of Foreign Languages of Sichuan University of Arts and Science. 


\section{The Colonists' Greed for Material Gain}

Through Marlow's experience, Heart of Darkness reveals the wide gap between the aspirations of the official doctrines of colonialism and its actual practices. Marlow's observations upon his arrival in Africa illustrate the material essence of the colonists.

The main character Kurtz is an ivory trader, sent by a shadowy Belgian company into the heart of the Congo Free State. With the help of his superior technology, Kurtz has turned himself into a charismatic demigod of all the tribes surrounding his station, and gathered vast quantities of ivory in this way. For Kurtz, ivory means everything. He is recognized as a top-class colonist, because the amount of ivory he imports is the sum of the total input of other colonists. In order to obtain more ivory, he spared no efforts to look for it everywhere, unscrupulously. In this country, you will not find ivory whether on the ground or underground, because no matter how deep the ivory buried, the genius Kurtz knows how to find them (Greiner, 1989, pp. 461-474). In order to take ivory from the local people, he even kills the natives. Therefore, Kurtz is also a thief, murderer, persecutor to some extent, yet he wants himself to be worshiped as a god.

Marlow still remembered that one day Kurtz said:

This lot of ivory now is really mine. The Company did not pay for it. I collected it myself at a very great personal risk. I am afraid they will try to claim it as theirs though. It is a difficult case. What do you think I ought to do-resist? Eh? I want no more than justice-no more than justice. (Conrad, 1983, p. 149)

Readers can see Kurtz is material. In order to realize his material dream, he became more and more greedy. As the incarnation of colonialism, Kurtz is such a person, who is full of desire for power and wealth. He went to Congo to seek fortunes, instead of the altruism that he claims. In Kurtz's opinion, if you show your leaders you have in you something that is really profitable, and then there will be no limits to the recognition of your ability.

Put simply, Kurtz is a perfect representation of society going mad with a greed for power and wealth. Heim personates imperialism's will to expand its domain over the earth and all its creatures, and he has stepped over the tempting edge of complete material and cannot be rescued.

\section{The Dark Side of Human Nature}

The second important theme of Heart of Darkness is to reveal the dark side of human nature. "Darkness" seems to pervade the novel. Marlow's tale begins and ends in literal darkness; the setting of the novel is often dark, such as when the steamboat is socked in by fog or when Marlow retrieves Kurtz; dark-skinned individuals inhabit the entire region; and of course, there is a certain philosophical darkness that permeates the work.

During Marlow's mission to find Kurtz, he is also trying to find himself. He, like Kurtz had good intentions upon entering the Congo. Conrad tries to show us that Marlow is what Kurtz has been, and Kurtz is what Marlow could become. Every human has a little of Marlow and Kurtz in them. Marlow says about himself, "I was getting savage", meaning that he was becoming more like Kurtz. Along the trip into the wilderness, they discover their true selves through the contact with savage natives.

The colonists' desire to constantly expand the territory and gain the massive wealth is called the will to power by Nietzsche (1844-1900). According to Nietzsche's view, whether you are strong or weak, the will to power is a unique human attribute, and human genetic attribute. People's desire in power, money, and beauty is the external form of human nature of the will to power in different circumstances. In Heart of Darkness, the 
will to power lies in the desire of the colonists to expand the colony and their greed for wealth. Conrad tries to show that, once the colonists live in particular environment, like the jungles of Congo, and far away from civilization, human nature is completely exposed. Readers can see how terrible the consequences can be, when a man is under the control of the will to power and lets this will to power continue to expand.

For example, Marlow's previous captain Fresleven had been killed in a scuffle with the natives. Fresleven's conflict with the natives arose from a misunderstanding about two black hens, he doubted he was cheated in the bargain, then he beat the chief of the village mercilessly. At last, the chief's son killed him in desperation at hearing his father yell. Here Fresleven acted as a cruel ruler, not as a civilized man at all. From the perspective of Nietzsche's theory of will to power, their atrocities only prove that once human beings are controlled by their desire for power in certain circumstances, the dark side of human nature will gain the upper hand, they will act in the way of the strong bullying the weak. Besides, there are contradictions within the colonists, when the Manager suggests that the "scoundrel" who is suspected of helping Kurtz procures his ivory, should be hanged as an example, his uncle agrees. Such actions are possible in the Congo, a region far from the light of civilized action. And Kurtz's most disturbing act, the placement of human heads atop poles surrounding his station house, is only possible in the concealed Congo. Here isolated from the rest of his own society, the colonists became corrupted by his power and isolation. The dark side hidden in the colonists is so obvious.

In the end, Kurtz died and cried, "The horror! The horror!" (Conrad, 1983, p. 149). Kurtz realizes the horrors that he has done when he utters his final words; society continues its vicious practice of imperialistic exploitation and incarceration without even a hint of conversion to less barbaric methods. But Kurtz's final statement means much more to Marlow; he sees it as an evaluation of society as well as Kurtz's own soul. For Marlow, the horrors are real and tangible; he understands Kurtz's statement because he has seen examples of the same types of horrors. While Kurtz has gone too far in reverting to savage ways, Marlow has learned a very important lesson that he will carry with him for the rest of his life. For Marlow, Kurtz's words are words to live by; they are an evaluation and a warning. In short, Marlow feels that Kurtz is a part of himself and possibly all of humanity. Kurtz has seen horrors that only Marlow would ever understand and profit from.

In conclusion, man's journey into self runs through Heart of Darkness. It is interesting to note that Marlow and Kurtz coming from the same background do not end up the same in the novel. Kurtz is the man who jumps off the edge of sanity and plunges into the darkness of insanity. Marlow is the man who goes to the edge of sanity, looks over the edge, and has enough strength not to go over to the other side. Of course, he is changed because of it (CHENG, 1995, p. 14).

\section{The Disillusionment of Civilization}

The third theme of the story is the disillusionment of civilization.

What drives the colonists to Africa? Marlow's aunt told him it was a glorious idea, they would bring civilization to the backward Africa. But Marlow has mentioned "profit" to his aunt, and at the Station, he gets a clearer answer.

At the Station, Kurtz does not force the natives to work for him by chains and fetters, but intimidates them by "thunder and lightening" (which are just guns and bullets) and gradually swings a spiritual control over them to make them work and even die for him willingly. His great influence upon the natives comes directly from his possession of modern weapons such as guns and bullets, which the natives have never seen before, and they take gun fires as "thunder and lightening". 
The weakness of the African natives is that they do not have modern weapons and have never seen them before; Kurtz shamefully takes this advantage and intimidates the African natives into surrender and even devotion to him. So he can maneuver them in his hunt for ivories in other villages. The heads of "criminals" fixed on the stakes surrounding Kurtz's residence are an astounding evidence of the notorious means of intimidation he uses upon the African natives.

A more revealing example of the failure of the "glorious idea" is the famous grove scene where Marlow finds, to his horror, a group of dying laborers.

Black shapes crouched, lay, sat between the trees, leaning against the trunks, clinging to the earth, half coming out, half effaced within the dim light, in all the attitudes of pain, abandonment, and despair... They were dying slowly-it was very clear. They were not enemies, they were not criminals, they were nothing earthly now, nothing but black shadows of disease and starvation lying confused in the greenish gloom. (Conrad, 1983, p. 20)

This scene is a striking antithesis of the "idea". The machinery and railways do not bring improvement but calamity to the natives, and instead of the savior, the colonists are the "devil" that makes Africa into an earthly hell.

So the "glorious idea" is only a hypocritical or even hideous excuse. In Heart of Darkness, the authenticity on the colonists' atrocity and the inhuman treatment to the black natives in Congo is not to be doubted. One enlightening conclusion drawn from Heart of Darkness is that, when the white colonists treat their African fellow creatures inhumanly, their own humanity is also undergoing a degrading process, hence the degradation and atavism of Kurtz. The colonists rob and murder in the name of enlightenment.

\section{Conclusion}

Heart of Darkness is a mixture of adventure story, psychological case study, political satire, black humor comedy, and skeptical meditation. This thesis analyzes its three themes: the Colonists' material essence, the dark side of human nature, and the disillusionment of civilization. But Conrad lived in the period of Queen Victoria, when the British Empire continued their colonial expansion crazily. Britain established a network of colonial cultural systems throughout the world, extending to about one fourth of the world. The exploration and expansion of colonial literature has its own superiority. Conrad has not been able to completely shake off the influence of the European centrism and racist consciousness. That is to say, when Heart of Darkness is attacking colonialism and exposing colonialist greed and hypocrisy, it also reveals the Western racial discrimination unconsciously.

\section{References}

CHEN, J. (1990). A history of English literature. Beijing: The Commercial Press.

CHENG, Y. J. (1995). Madness and fiction in Conrad, Woolf and Lessing. Michigan: UMI Company.

Conrad, J. (1983). Heart of darkness. London: Penguin books.

Conrad, J. (1999). Preface. In The nigger of the "Narcissus". New York: Dover Publications.

Greiner, D. J. (1989). Heart of darkness: Out of Africa some new thing rarely comes. Journal of Modern Literature, 15(4), 461-474. 